\title{
Russell-Meinong Tartışması Üzerine
}

\section{On The Russell-Meinong Debate}

\author{
Çağdaş Burak Karataş ${ }^{1}$ (])
}

'İstanbul Üniversitesi, Edebiyat Fakültesi, Felsefe Bölümü, İstanbul, Türkiye

ORCID: Ç.B.K. 0000-0001-5785-7230

Sorumlu yazar/Corresponding author: Çağdaş Burak Karataş

İstanbul Üniversitesi, Edebiyat Fakültesi, Felsefe Bölümü, İstanbul, Türkiye

E-mail/E-posta: karatascagdasb@gmail.com

Başvuru/Submitted: 15.12.2020

Kabul/Accepted: 21.12 .2020

Atıf/Citation: Karatas, Cagdas Burak. (2020). "Russell-Meinong Tartışması Üzerine" Felsefe Arkivi-Archives of Philosophy, 53: 35-54. https://doi.org/10.26650/arcp.841355

\section{ÖZET}

Russell-Meinong tartışması, geçtiğimiz yüzyılın başlarında gerçekleşmiş, nesne sorununu konu eden bir tartışmadır. Tartışmanın odak noktaları; varlığın nasıl anlaşılması gerektiği, nelerin var olduğu, nesne olma koşulları ve bu bağlamda ontoloji-mantık ilişkisidir. Farklı ilkeler ve yöntemler benimseyen iki düşünür, bazı konularda uzlaşı içinde olmakla birlikte çeşitli konularda görüş ayrılıkları içindedir. Russell, temel olarak, varlık-dışı nesneleri içeren önermelerin çelişmezlik ve 3.halin olanaksızlığı ilkelerini çiğnediğini öne sürerek bu nesnelerin ontolojiden elenmesini savunmaktadır. Meinong'un nesne kuramı, özetle, varlık tarzlarını ayırmakta ve mantık ilkelerinin belirleyiciliğini sınırlandırmaktadır. Bu düşüncelere cevap verme arayışı, Russell'ın betimlemeler kuramını ortaya koymasını sağlamıştır. Betimlemeler kuramının getirdiği çözümler ve kuramın yalınlığı, yıllar boyunca bu tartışmada haklı olanın Russell olduğunun düşünülmesine neden olmuştur. Ancak metafizik ve mantıktaki çeşitli gelişmeler ile tartışma yeniden ele alınmıştır. Bu yeniden ele alma sayesinde tartışmaya ilişkin yeni yorumların ileri sürülmesinin olanağı ortaya konmuştur. Buna bağlı olarak çeşitli çağdaş metafizik kuramların ortaya çıkması söz konusu olmuştur. Bu çalışmada öncelikle Russell'ın tartışmanın gerçekleştiği dönemdeki düşünceleri serimlenecek ve Meinong'a getirdiği eleştiriler ortaya konacaktır. Daha sonra Meinong'un nesneler kuramı kapsamlı şekilde sergilenecektir. Böylece, iki düşünürün düşünceleri karşılaştırılmaya tabi tutularak aralarındaki görüş benzerlikleri ve farklılıkları saptanacaktır. Bu çerçevede, tartışmaya ilişkin bir değerlendirme sunularak tartışmanın yeniden ele alınmasının nedenleri, tartışmaya dair öne sürülen çeşitli yorumlar ve tartışmanın güncel metafizikteki yansımaları açıklanacaktır.

Anahtar Kelimeler: Russell, Meinong, ontoloji, mantık, gönderim

\section{ABSTRACT}

The Russell-Meinong debate is a discussion that took place at the beginning of the last century. The focal points of the discussion are basically about how existence should be understood, what is said to exist, the conditions of being an object, and in this context, the relation between ontology and logic. These two thinkers agree with each other on some issues, but they differ on others. Russell argues that propositions involving non-existent objects violate the principles of noncontradiction and excluded middle, and that these objects should be eliminated from ontology. Meinong's object theory, distinguishes the modes 
of existence and limits the determination of the principles of logic. His search for answers to these ideas led Russell to introduce his theory of descriptions. The solutions provided by the theory of descriptions and its simplicity have led to the thought that Russell was right in this debate over the years. However, with various developments in metaphysics and logic, the debate has been reconsidered. Thanks to this reconsideration, the possibility of putting forward new interpretations of the debate has been revealed. Consequently, various contemporary metaphysical theories have emerged. In this study, first, Russell's criticisms against Meinong will be put forward. Then, Meinong's theory of objects will be presented comprehensively. Thus, the similarities and differences between their understanding will be evaluated. In this framework, the reasons for reconsidering the debate, and various interpretations put forward on it, and the reflections of the debate in contemporary metaphysics will be expounded.

Keywords: Russell, Meinong, ontology, logic, denotation

\section{Giriş}

Russell-Meinong tartışması, 20.yy. başlarında gerçekleşmiş ${ }^{1}$, sonucunda yüzyılın paradigması ${ }^{2}$ olarak adlandırılan betimlemeler kuramının ortaya çıkmasına neden olmuş ve geçtiğimiz on yıllarda yeniden yorumlanmaya ${ }^{3}$ başlamıştır. Tartışma temel olarak bir nesne kuramı tartışmasıdır. İki düşünür "neler vardır", "bir nesne olmanın koşulları nelerdir" sorularını farklı yöntemlerle, buna bağlı olarak farklı sonuçlara vararak ele almaktadır. ${ }^{4}$

İki düşünür arasında hem uzlaşılan noktalar hem de görüş ayrılıkları söz konusudur. Meinong, Russell ile benzer şekilde dış dünya gerçekliğini savunmaktadır. İki düşünür için görüş ayrılığı dış dünyanın nelerden oluştuğu konusunda çıkmaktadır. Russell'a göre hem doğru hem

1 İki düşünür bu tartışma sürecinde karşılıklı makaleler ve mektuplarla bu konuları karşılıklı tartışmışlardır. Tartışma yoğun haliyle 1907'ye kadar sürmüştür. Tartışma, Russell'ın 1899 yılında Mind dergisine Meinong'un Uber die Bedeutung des Weberschen Gesetzes (1896) başlıklı eserine bir inceleme yazmasıyla başlamıştır. Detaylı bilgi için bkz.: Peter Simons, Philosophy and Logic in Central Europe from Bolzano to Tarski, (Springer, 1992), 171. İlerleyen zamanda Meinong 1902 yılında önemli eserlerinden biri olan Über Annahmen’i, Russell ise 1903 yılında Principles of Mathematicsi yayımlamıştır. Russell, hemen bir yıl sonra yine Mind dergisine Meinong's Theory of Complexes and Assumptinons başlıklı, üç makaleden oluşan yeni bir Meinong incelemesi yazmıştır. Yine 1904'te, 12 Aralık gününde Meinong’a bir mektup yazmıştır. Meinong aynı yılda bir diğer önemli eseri olan Theory of Objects (Über Gegenstandstheorie) adlı eserini yayımlamıştır. Russell 1905 yılında hem meşhur makelesi Gönderim Üzerine’yi yayımlamıştır hem de yine Mind dergisi için, Meinong'un Theory of Objects adlı eserini incelemiştir. Meinong'un 1906 yılında yayımladığı Über Die Stellung Der Gegenstandstheorie im System der Wissenschaffen adlı eserine Russell tarafından 1906 ve 1907 yılında incelemeler yazılmıştır. Tartışma 1906 ve 1907 yıllarında aynı zamanda mektuplaşmalar üzerinden de sürmüştür. Bu yıllardan sonra ikili arasında karşılıklı tartışma sona ermiştir ancak Meinong 1910 yılında önemli eseri Über Annahmen’in ikinci edisyonunu yayımlamış, 1920'ye kadar eser vermeye devam etmiştir. Russell da bu yılları oldukça üretken geçirmekle birlikte eserlerinde Meinong'u ansa da muhatabı ile doğrudan bir tartışma sürdürmemiştir. Detaylar için bkz.: Janet Farrell Smith, "The Russell-Meinong Debate”, Philosophy and Phenemenological Research 45 (3), (1985), 345-347.

2 Russell'ın "Gönderim Üzerine” adlı makalesiyle ortaya koyduğu betimlemeler kuramı F. Ramsey tarafindan "yüzyılın paradigması" şeklinde betimlenmiştir. Bkz.: Nicholas Griffin, "Russell's Critique of Meinong’s Theory of Objects”, Grazer Philosophische Studien 25 (1), (1985): 375. Güven’in aktardığına göre, bu kuramı analitik felsefenin başlangıcı şeklinde yorumlayan düşünürler de söz konusudur. Kuramın analitik felsefe içindeki yeri ve analitik felsefenin karakteristik niteliklerine ilişkin detaylı inceleme için bkz.: Özgüç Güven, "Analitik Felsefenin Tanımlayıcı Özellikleri Üstüne”, Kutadgubilig Felsefe-Bilim Araştırmaları 28 (Ekim 2015): 11-24.

3 Yeniden yorumlama ihtiyacının nedenleri ve bu yorumlamanın sonuçları ileride ortaya konacaktır.

4 Sözü edilen yöntem farklılığı ve uzlaşılmayan konular ileride detaylı açılacaktır. 
de yanlış önermelerin zihin-dışı gerçekliği söz konusuyken Meinong’a göre bu durum yalnızca doğru önermeler için geçerlidir. Russell, uzam-zamanda var olan (exist) somut nesneler ve uzam-zamanda olmayan ancak bir biçimde kalıcılığı (subsist) olan özellik, bağıntı gibi tümel nesnelerin var olduğunu düşünmektedir. Ancak Meinong’a göre, bu nesnelerin yanı sıra ne var olan ne de kalıcı olan nesneler söz konusudur. Meinong, bu soruları incelemek üzere metafiziği de barındıran ${ }^{5}$ bir "nesneler kuramı (theory of objects)" önermektedir. Russell ise mantık temelli bir ontoloji ölçüsünde inceleme yapmaktadır.

Bu makalede öncelikle Russell'ın “Gönderim Üzerine (bundan sonra GÜ) öncesi ve GÜ sonrasında Meinong’un nesneler kuramına getirdiği eleştiriler sergilenecektir. Sonrasında Meinong'un nesneler kuramı detaylıca ele ortaya konacaktır. Böylece iki düşünürün uzlaştığı ve farklı düşündüğü noktalar ortaya çıkarılacaktır. Bu bağlamda Russell'ın eleştirileri ile Meinong’un cevapları irdelenerek tartışmaya ilişkin bir değerlendirme sunulacaktır.

\section{Russell'ın Meinong Eleştirisi}

Russell, 1890'lı yılları İngiliz Hegelciliğinin baskın olduğu Cambridge Üniversitesi’nde bir Hegelci olarak geçirmektedir. ${ }^{6}$ Ancak, bu on yılın tam sonunda ${ }^{7}$, Peano ve Moore etkisiyle Hegelci İdealizm'den koparak Gerçekçi ve Çoğulcu bir ontolojik pozisyona geçiş yapmıştır. ${ }^{8}$ Bu dönüşüm Russell'ın ilgisini gerçekçi ontoloji öneren düşünürlere yöneltmiştir. ${ }^{9}$ Bu düşünürlerden birisi Meinong'dur.

Russell bu dönemde Meinong ile genel anlamda benzer düşüncelere sahiptir. Meinong’un düşüncelerine olan takdirini 1904 yılında yazdığı mektupta, "onunla neredeyse tam bir uzlaşı içinde olduğunu” ifade ederek göstermektedir. ${ }^{10}$ Bu benzerliklerden ilki, Russell'ın önerme adını verdiği var olanla Meinong'un "Objectiv” adını verdiği nesnellerin ${ }^{11}$ Russell tarafından benzer

5 Meinong’un metafizik ile kendi nesne kuramı arasındaki ilişkiyi nasıl düşündüğü ileride açıklanacaktır.

6 "O zamanlar tamamıyla Hegelciydim ve tüm gerçekliğin zihinsel olduğunun kanıtıyla sonuçlanacak tam bir bilimler diyalektiğini kurmayı amaçlamıştım. ... Kant ve Hegel'in çatıştığı her yerde Hegel'den yana oldum.” Russell bu cümleleri o dönemki Hegelci görüşlerini betimlemek üzerine yazmıştır. Bertrand Russell, My Philosophical Development, (Simon and Schuster, New York, 1959) 42.

7 Russell, 1903 'te yayımlanan, İdealizmden Gerçekçiliğe geçişinin metni Principles of Mathematicsin taslağını tam olarak yüzyılın son gününde, 31 Aralık 1899'da bitirdiğini aktarmaktadır. Bkz.: Russell, My Philosophical Development, 73.

8 Russell, My Philosophical Development, 11-12. Sözü edilen gerçekçilik zihin-dışı bir dünyanın gerçekliğini kabul eden ontolojik bir pozisyondur. Çoğulculuk ise gerçekliğin tek olmadığını, bir çokluk barındırdığını iddia etmektedir. Söz gelimi, gerçekliğin pek çok somut nesne ve bağıntıdan oluştuğu iddiası böyle bir görüşe örnektir.

9 Bu düşünürlere Moore ve Frege de dahildir ancak metnin bağlamı gereği bu konu detaylandırılmayacaktır.

10 Smith, "The Russell-Meinong Debate", 347.

11 "Objectiv" sözcüğü için Arda Denkel "nesnel” sözcüğünü tercih etmektedir. Arda Denkel, Yönletim-Dil Felsefesinde Bir Konu, (Boğaziçi Üniversitesi Yayınları, No.281, 1981), 7-8. Tuğba Yavuz ise "ne-ise-ne” sözcügünü tercih etmektedir. Tuğba Yavuz, "Varolmayan Nesneler Semantiği”, (Doktora Tezi, İstanbul Üniversitesi, 2020), 132. Meinong'un bu var olanları birer nesne olarak görmesi ve zihin-dışı gerçeklikleri olduğunu düşünmesi "nesnel” sözcüğü tarafından karşılandığı için Denkel’in önerisi tercih edilmiştir. Meinong düşüncesinin ayırt edici kavramlarının çevirilerinde aksi belirtilmediği sürece Denkel'in çevirileri kullanılacaktır. 
var olanlar olarak görülmesidir. ${ }^{12}$ Yargıların hakkında olduğu bu var olanlar, zihin-dışı gerçekliğe sahip var olanlar olarak düşünülmektedir. Bir diğer benzerlik ise iki düşünürün de bağıntı ve özellik gibi tümellere gerçeklik ${ }^{13}$ atfediyor olmalarıdır.

Russell'ın Meinong eleştirisi süreklilik arz etse de GÜ'den önceki ve GÜ ile geliştirilen eleştiri biçiminde ayrılmalıdır. GÜ öncesi önermenin ele alınışı bağlamında bir eleştiri öne sürülmektedir. GÜ ve sonrasında, eleştirinin odağ 1 mantık ilkelerinin çiğnenmesidir.

Öncelikle Russell'ın tartışmanın sürdüğü dönemdeki düşüncelerini açalım. Russell, Matematiğin İlkeleri ile ortaya katı bir gerçekçilik koymaktadır. Ona göre, dilde yer alan var olanlar terimlerdir. Örneğin, sözcüklerin yer aldığı önermeler sözcüklerden değil doğrudan o sözcüklerin yerine durduğu terimlerden oluşmaktadır. ${ }^{14}$ Terimlerin tanımı ise şu şekildedir:

"Düşüncenin nesnesi olabilen veya herhangi doğru ya da yanlış önermede belirebilen veya bir olarak sayılabilen her şeyi bir terim olarak adlandırıyorum. Böylece, bu felsefi sözcük dağarcığındaki en geniş sözcüktür. Bunu birim [unit], birey [individual] ve var olan [entity] sözcükleriyle eş anlamlı kullanacağım." 15

Russell'ın düşüncesine göre, terimler kendinde birliği olan, kendine özdeş ${ }^{16}$ var olanlar olarak dilde doğrudan yer almaktadırlar. Böylece dil ile dünya arasında bir dolayım ilişkisi gözetilmediği ortaya çıkmaktadır. Bu durum, dilsel ifadelerin olduğu gibi bir gerçekliği olduğu sonucunu ortaya çıkarmaktadır. Söz gelimi, "Masadaki kalem yeşildir” önermesi doğruysa; doğru önerme veya yanlışsa, yanlış önerme şeklinde zihin-dışı bir gerçekliğe sahiptir. ${ }^{17}$ Paralel olarak, önermenin parçaları olan "masadaki kalem” ve "yeşil olmak” birer zihin-dışı gerçeklik taşımaktadırlar. Bu

12 Bertrand Russell, "Meinong's Theory of Complexes and Assumptions (II.)”, Mind 13(51), (1904), 350. Aradaki tek fark şudur: Russell, önermeleri insan zihnine “aşkın” nesneler olarak düşünürken Meinong’a göre olanaksız nesneler söz konusu olduğunda nesneller düşünceye içkin olmaktadır. Bernard Linsky, "Russell's Notes for Meinong's Theory of Complexes and Assumptions”, Russell: the Journal of Bertrand Russell Studies, 33, (2013), 145. Meinong, daha sonra nesnellerin yargıların hakkında olduğu ve kalıcılıkları olan nesneler olduklarını belirtmektedir. Bkz.: Alexius Meinong, "Theory of Objects", Realism and the Background of Phenomenology, çev. Isaac Levi, D.B. Terrell, Roderick M. Chisholm, ed. Roderick M. Chisholm, (Glencoe: Free Press, 1960), 80.

13 Meinong, bu türden var olanların kalıcılık taşıdığı düşüncesindedir. Bu bağlamdaki görüşleri ileride detaylıca açıklanacaktır. Russell'a göre de bağıntılar, nitelikler gibi var olanların zihin-dışı gerçeklikleri vardır. Bkz.: Bertrand Russell, Principles of Mathematics, (Routledge, London and New York, 2010), 224-226. Ayrica bkz.: Ivory PribramDay, "Meinong's Multifarious Being and Russell's Ontological Variable: Being in Two Object Theories across Traditions at the Turn of the 20th Century", Open Philosophy 1 (1), (2018), 316.

14 Russell, Principles of Mathematics, 48.

15 Russell, Principles of Mathematics, 44.

16 Russell, Principles of Mathematics, 45.

17 Russell, doğruluk ve yanlışlık meselesini tam olarak çözemediğini belirtmektedir. Ancak ona göre, doğru önermeler, yanlış önermelerin sahip olmadığı "bildirilmek (asserted)” özelliğine sahiptir. Bkz.: Russell, Principles of Mathematics, 50. 
görüş, “yuvarlak kare yuvarlaktır” önermesi ele alındığı zaman "yuvarlak kare” türünden"18 nesnelere ontolojik bağ $\operatorname{ll}_{1} \breve{g ̆ g}_{1}{ }^{19}$ beraberinde getirmektedir.

Russell, kuramının hem yanlış önermelere hem de var-olmayanlara ontolojik bağlılık tanımasını $1^{20}$ sorunlu bulmaktadır. Bu konuya ilişkin soruşturma ve Meinong'a karşı argüman geliştirme çabası “Gönderim Üzerine (On Denoting, 1905)” adlı makalesinin ortaya çıkmasına neden olmuştur. Fakat Russell GÜ'de geliştirdiği argümanlardan önce de var-olmayan nesneleri kabul etmekten yana değildir. Bu durumun ilk izi 1904'te Meinong'a yazılan mektupta şu ifadelerle ortaya konmaktadır ${ }^{21}$ :

“...var olmayan [non-existent] nesneleri kabul etmenin zor olduğu düşünüyorum. Altın dağ veya yuvarlak kare gibi bir durumda, kişi anlam [sense,] ve gönderimi [reference] ayırmalıdır (Frege'nin ayrımıyla uyum içinde). Anlam nesnedir ve varlık [being] sahibidir, diğer yandan, gönderim bir nesne değildir."

Russell, göründüğü üzere, var-olmayan nesnelere karşıt düşüncesini22 ${ }^{22}$ Frege'ci bir bakış açısından öne sürmektedir. 1905 yılı temmuz ayında yayımlanan "Existential Imports of Propositions" başlıklı metinde, "insan başlı at", "yuvarlak kare”, "Fransa’nın şimdiki kralı" ve "Apollo" gibi nesneler yine aynı bakış açısıyla reddedilmektedir. ${ }^{23}$ Bir diğer eleştiri ise önermenin ele alınma tarzıyla ilişkilidir. Russell'a göre, Meinong'un düşüncesinin aksine, önerme ile önermenin parçaları arasında bütün-parça ilişkisi vardır. ${ }^{24}$ Dolayısıyla, önermenin bir parçası varlık sahibi değilse önermenin kendisi de bir bütün olarak varlık sahibi değildir. ${ }^{25}$

18 Bu düşünce takip ediliği zaman, “yuvarlak kare” gibi olanaksız nesnelerin yanı sıra "Sherlock Holmes” gibi kurgu nesneleri, "Pegasus" gibi mitolojik nesneler için de aynı durum geçerli olmaktadır.

19 Russell bu bağlamda varlık (being) ile var olma (existence) arasında bir ayrım gözetmektedir. Ona göre düşüncenin olanaklı bütün nesneleri, sayılabilen her şey varlık sahibidir, ancak varlık sahibi olan her şey var olma niteliğine sahip olmayabilir. Bkz.: Russell, Principles of Mathematics, 72.

20 Bu noktada Russell'ın yalnızca bu türden nesneleri sorunlu bulduğunu vurgulamak gerekir. Ona göre, uzamzamansal olarak var olan fiziksel nesneler ile kalıcılık taşıyan bağıntılar, matematiksel nesneler varlık sahibidirler. Bkz.: Smith, "The Russell-Meinong Debate", 307.

21 Smith, "The Russell-Meinong Debate", 348.

22 Simons, Russell'ın ilk kez bu mektupta varlık-dışı nesneler tartışmasını gündeme getirdiğini belirtmektedir. Bkz.: Simons, Philosophy and Logic in Central Europe from Bolzano to Tarski, 173.

23 Bertrand Russell, "Existential Import of Propositions", içinde The Collected Papers of Bertrand Russell Volume 4: Foundations of Logics 1903-1905, ed. Alasdair Urquhart ve Albert C. Lewis (Routledge, 1994), 487. Russell bu metninde Meinong gibi var-olmayan nesneleri kabul eden bir mantıkçı olan Hugh MacColl'u (1837-1909) eleştirmektedir. Ayrıca bkz.: Simons, Philosophy and Logic in Central Europe from Bolzano to Tarski, 174.

24 Bertrand Russell, "Meinong's Theory of Complexes and Assumptions (III.)", Mind 13(52), (1904), 517.

25 Bertrand Russell, "Meinong's Theory of Complexes and Assumptions (I.)”, Mind 13(50), (1904), 213. İleride daha detaylı açılacağı üzere Meinong bu ilişkiyi kabul etmemektedir. 
1905 yılının ekim ayına geldiğimizde GÜ yayımlanır. Russell, gönderim deyimleri (denoting phrases) adını verdiği ifadelerin tek başına anlamlı olmadığını yani bir gönderimleri olmadığın ${ }^{26}$ göstermek üzere üç bilmeceyi incelemektedir ${ }^{27}$ : İlk bilmecede, "Scott, Waverley’nin yazarıdır" önermesi üzerinden $\mathrm{a}=\mathrm{b}$ türünden özdeşlikler incelenmektedir. İkinci bilmece, "Şimdiki Fransa kralı keldir” önermesi üzerinden, bu önerme ile değillenmiş hali olan "Şimdi Fransa kralı kel değildir” önermesinin doğruluk değerlerini incelemektedir. 3.halin olanaksızlığı ilkesi gereği bu önermelerden birisi doğru, diğeri yanlış olmalıdır. Üçüncü bilmece, yokluk bildiren deyimlerin özne yerinde nasıl durabildiğini incelemektedir. Burada incelenen, A ve B arasında bir fark olmadığı durumda, "A ve B arasındaki fark yoktur" önermesinde özne yerinde duran "A ve B arasındaki fark" deyiminin gönderimi sorunudur.

İlk bilmece, betimlemeler ile adlar arasındaki fark açığa çıkarılarak şu şekilde çözülmektedir ${ }^{28}$ :

(1) “Scott, Waverley’nin yazarıdır."

(2) "Scott, Scott'tur."

“Waverley'nin yazarı" yerine "Scott” konulduğu zaman ortaya çıkan (2)'nin (1) ile aynı önerme olmadığı açıktır; (1)'in bilgi içeriği söz konusuyken (2) bir totolojidir. Bu farkın nedeni "Scott" 1 bir ad, "Waverley'nin yazarı"nın bir betimleme olmasıdır. Diğer yandan 3.halin olanaksızlı̆̆ı ilkesi gereği, eğer "Waverley'nin yazarı" "Scott" anlamına gelmiyorsa bu betimleme "Scott" dışında başka bir anlama gelmelidir. Ancak bu durumda da doğru olduğunu bildiğimiz (1)'in yanlış olması gerekecektir. "Waverley’ nin yazarı" ne Scott anlamına ne de Scott dışında bir anlama gelebildiğinden bu gönderim deyimi, tek başına anlamlı olmayan bir betimleme olmalıdır. (1) önermesinin çözümlenmesi ise "öyle bir x vardır ki; bu x, Waverley’i yazmıştır ve herhangi bir y Waverley’i yazdıysa x ile y özdeştir, Scott x ile özdeştir” şeklindedir. Böylece, Waverley’nin yazarı" gönderim deyimi gibi "Scott” özel adının da önermede doğrudan yer almadığı, doğrudan gönderim yapmadığı ortaya konmaktadır.

İkinci bilmece, önermenin aynı yöntemle çözümlenmesiyle aşılmaktadır. ${ }^{29}$ 3.halin olanaksızlığı gereği "Şimdiki Fransa kralı keldir” ve "Şimdiki Fransa kralı kel değildir" önermelerinden biri yanlışsa diğeri doğru olmalıdır. Ancak bir Fransa kralı olmadığından her iki önermeye de bir doğruluk değeri atanamıyor gibi görünmektedir. "Şimdiki Fransa kralı keldir” önermesinin

26 Russell'ın bu deyimleri incelemesinin bir nedeni, kendi katı gerçekçi kuramına düzenleme getirmektir. Griffin, Russell'ın amacının gönderim deyimlerinin anlam-gönderim ilişkisini incelemek olduğunu belirtmektedir. Bkz.: Griffin, "Russell's Critique of Meinong's Theory of Objects”, 380. Fakat, bu deyimlerin gönderimleri olduğu düşüncesi, nesne olarak kabul edilen var olanlar kümesini genişletmektedir. Russell, bu durum nedeniyle ontolojisini sadeleştirmek amacıyla bu kuramı önermektedir. Smith'in aktardığına göre, bir diğer nedeni ise Meinong’un yargıyı hatalı bir şekilde özne-yüklem formunda düşünerek özne yerinde duran dilsel ifadelerin gönderimlerinin olduğunu düşünüyor olmasına cevap vermektir. Bkz.: Smith, "The Russell-Meinong Debate”, 309, 311. Bu tartışma makalenin 4.bölümünde tartışılacaktır.

27 Bertrand Russell, "On Denoting”, Mind, New Series, 14(56), (1905), 485. Makale, Türkçeye kazandırılmış bir makaledir. Bkz.: Bertrand Russell, "Gönderim Üzerine”, çev. Alper Yavuz, Felsefe Tartışmaları 49 (2015): 55-72.

28 Russell, "On Denoting”, 487-489.

29 Russell, “On Denoting”, 490. 
aslında bir Fransa kralının varlığını iddia ettiği, önerme "öyle bir x vardır ki; bu x Fransa kralıdır ve keldir” şeklinde çözümlendiği zaman görünür olmaktadır. Ancak bu iddia yanlıştır zira böyle bir varlık yoktur. Dolayısıyla, doğruluk değerine sahip değilmiş gibi görünen önermenin yanlış olduğu, önermenin bir parçasının yanlış olduğu gösterilerek sergilenmektedir.

$\mathrm{Bu}$ iki bilmecenin çözüm yöntemi üçüncü bilmeceyi kolaylıkla aşılabilir kılmaktadır. ${ }^{30}$ "A ve B arasında fark yoktur" önermesi, "öyle bir x yoktur ki; bu x, A ve B arasındaki fark olsun” şeklinde çözümlenerek özne yerinde duran "A ve B arasındaki fark" deyiminin aslında bir varlık bildirmediği gösterilmektedir.

$\mathrm{Bu}$ argümanlar, Meinong'a karşı bir düşünce geliştirmeyi olanaklı kılmaktadır. Meinong’a göre, "Yuvarlak kare yuvarlaktır" önermesi, "yuvarlak kare” olanın "yuvarlak” olma özelliğini bildirdiği için doğru bir önermedir. Russell’ın karşı argümanı ${ }^{31}$ şu şekildedir:

(3) "Yuvarlak kare, yuvarlaktır."

(4) "Yuvarlak kare, karedir."

Eğer yuvarlak kare, kareyse o halde aynı zamanda yuvarlak olmayan olmalıdır. Bu durumda;

(5) "Yuvarlak kare, yuvarlak olmayandır."

Görüldüğü üzere (3) ve (5) arasında bir çelişki ortaya çıkmaktadır. Böylece, "yuvarlak kare” gibi gönderimi olmayan deyimleri içeren önermelerin mantık ilkelerini çiğnediği gösterilmektedir.

Bu noktadan hareketle (3)'ün doğruluk değeri de yanlış olmaktadır. Bu önerme betimlemeler kuramı gereği,

(6) "Yuvarlak ve kare olan yalnızca bir x varlığı vardır ve o varlık, yuvarlaktır." şeklinde çözümlenmektedir.

Çözümleme yoluyla önermenin, yuvarlak ve kare olan bir varlık olduğu iddiasında bulunduğu ortaya çıkmaktadır. Fakat böyle bir varlık olduğu iddiası çelişkiye yol açması nedeniyle yanlıştır. ${ }^{32}$ Dolayısıyla, Russell'a göre, çelişmezlik yasası çiğnenmeden bu türden deyimlerin gönderiminden söz etmek olanaksızdır. ${ }^{33}$

30 Russell, "On Denoting”, 490-491.

31 Russell, "On Denoting”, 491.

32 Russell bu soruna neden olan nesneler içerisine gönderimi olmayan bütün nesneleri katmaktadır. Meinong’un kendisine yönelttiği, yuvarlak karenin yanı sıra altın dağ türünden nesneleri de reddetmesi gerekliliği eleştirisine, 1906 yılında yazdığı mektupta, "Olanaksız nesnelerle ilgili olarak, altın dağın yuvarlak kareyle birlikte reddedilmesi gerektiği sonucundan rahatsızlık duymadım. Bu nedenle "Gönderim Üzerine” adlı makalemde Fransa Kralı örneğini kullandım.” ifadesiyle cevap vermektedir. Smith, “The Russell-Meinong Debate”, 349.

33 Russell bu eleştirisini "esas itirazı" olarak nitelendirir ve "olanaksız nesneler oluşturucular arasında olduğunda çelişmezlik yasası reddedilir” ifadesiyle ortaya koyar. Bkz.: Bertrand Russell, "Review of Meinong and Others, Untersuchungen zur Gegenstandstheorie und Psychologie", içinde The Collected Papers of Bertrand Russell Volume 4: Foundations of Logics 1903-1905, ed. Alasdair Urquhart ve Albert C. Lewis (Routledge, 1994), 598. 
Russell'a göre, gönderimi olmayan deyimleri içeren önermeler aynı zamanda 3.halin olanaksızlığı ilkesini çiğnemektedir. Meinong’un kuramına göre, x gibi bir nesne varlık-dışıysa, "y, x’ten farklıdır" ile "y, x’ten farklı değildir” önermelerinin ikisi de doğru olabilmektedir. ${ }^{34}$ Russell, bu düşüncenin sayılabilirlik sorununa da neden olduğunu öne sürmektedir. Ona göre, varlık sahibi olmak sayılabilir olmaktır. ${ }^{35}$ Çelişkili nesneler kendilerine özdeş olmadığı için sayılabilir değillerdir. Örneğin, $x$ ve y birbirlerinden farklı var olanlarsa $\{x, y\}$ kümesinin eleman sayısı 2 olmaktadır. Eğer birbirlerine özdeşlerse eleman sayısı 1 olmaktadır. Ancak, $\{x, y\}$ kümesinin eleman sayısının aynı anda hem 1 hem de 2 olması olanaklı değildir. $\mathrm{O}$ halde, bu türden nesneler 3.halin olanaksızlığı ilkesini çiğnediği için varlık sahibi değillerdir. ${ }^{36}$

Russell'ın önerisi basittir. Yapılması gereken, varlık-dışı nesnelere gönderim yapıyormuş gibi görünen deyimleri içeren önermeleri, betimlemeler kuramı yoluyla parçalara ayırmaktır. ${ }^{37}$ Böylece bu deyimlerin varlık bildirmediklerini göstermek ve bu önermelerin yanlış olduğunu ortaya koymak olanaklı olmaktadır. Betimlemeler kuramı, ortaya koyduğu bu olanakla hem "neler vardır" sorusuna cevap veren hem sahte sorunları eleyebilen hem de Meinong'un nesne kuramına kıyasla daha yalın bir ontoloji öneren bir yöntem olarak sunulmaktadır. ${ }^{38}$

\section{Meinong'un Nesne Kuramı}

Meinong'un felsefeye yönelimi hocası Franz Brentano etkisiyle gerçekleşmiştir. ${ }^{39}$ İlgi kurduğu temel felsefi problem ise nesneler kuramı olmuştur. Meinong bu bağlamda hangi nesnelerin var olduğu, var olmanın nasıl anlaşılması gerektiği ve var olanların özellikleri gibi sorularla ilgilenmiştir. Meinong her ne kadar bu sorulara ilişkin cevapları bağlamında özgün bir düşünür olsa da ona benzer görüşler öne süren tarihsel öncüllerinden de söz edilebilir. Bunların arasında

34 Russell, bu düşünceyi Meinong’un öğrencisi Ameseder'e referans vererek örneklemektedir ve Ameseder'in hocasıyla benzer düşüncede olduğunu eklemektedir. Russell, Review of Meinong and Others, Untersuchungen zur Gegenstandstheorie und Psychologie”, s. 598.

35 Russell, Principles of Mathematics, 72.

36 Russell, "Review of Meinong and Others, Untersuchungen zur Gegenstandstheorie und Psychologie”, 598.

$37 \mathrm{Bu}$ işlemle önermelerin altında yatan mantıksal biçim ortaya konmaktadır. Dolayısıyla yapılan inceleme, mantıksal dilden hareketle yapılmaktadır.

38 Russell'ın betimlemeler kuramıyla ortaya koyduğu argümanın, Meinong’un nesne kuramını alt ettiği düşüncesi uzun süre hâkim olmuştur. Hatta Swanson, Ryle’ın 1970'lerin başında yazdığı bir makalesine, "Meinong'un nesne kuramının ölmüş, gömülmüş ve canlanamayacak olduğunu baştan açıkça kabul edelim” ifadesiyle başladığını aktarmaktadır. Bkz.: Carolyn Swanson, Reburial of Nonexistents: Reconsidering the Meinong-Russell Debate, (Rodopi, Amsterdam-New York, 2011), 1.

39 Uğur Ekren, "Alexius Von Meinong ve Nesneler Teorisi”, Kutadgubilig Felsefe-Bilim Araştırmaları 17 (Mart 2010), 11. Ekren, Meinong'un Brentano etkisiyle gerçekleştirdiği felsefi çalışmalarını "Hume’un Nominalizmini ve soyutlama teorisini konu alan bu çalışma Hume-Studien I başlığıyla Sitzungs-berichte der Wiener Akademia der Wissenschaften'de 1878 yılında neşr edilmiştir. Meinong arkasından bu çalışmanın devamı olan ve Hume’un bağıntılar teorisini ele alan Hume-Studien II'yi 1882'de basmıştır. Meinong bu çalışmalarından sonra nesneler teorisini geliştirmeye başlamı̧s ve 1904-1917 yıllarında bu konuda ve başka konularda çok önemli eserler yayınlamıştır.” ifadesiyle aktarmaktadır. Bkz.: Ekren, “Alexius Von Meinong ve Nesneler Teorisi”, 11. Brentano'nun diğer bir etkisi ise "yönelimsellik (intentionality, intentionale)" kavramı aracıllğıyla yönelinen nesnenin zihinsel edimden ayrı olduğu anlayışıdır. Bkz.: Simons, Philosophy and Logic in Central Europe from Bolzano to Tarski, 163. Meinong, bu noktada yönelinen nesnelerin zihinsel edimden ayrı, kendinde bir gerçekliği olduğu düşüncesindedir. Bkz.: Roderick M. Chisholm, “Beyond Being and Nonbeing”, Philosophical Studies 24 (4), 1973, 252. 
Stoacılar, Petrus Abelardus, Thomas Reid öne çıkmaktadır. ${ }^{40}$ Bu düşüncenin ortak noktası varlıkdışı (non-being) nesneleri kabul eden ontoloji ve epistemoloji önermeleridir. ${ }^{41}$

Meinong düşünülebilir her şeyi nesne (Gegenstand) olarak kabul eden bir nesne kuramı önermektedir. ${ }^{42}$ Onun nesneler kuramı, metafiziği de içine alan geniş bir soruşturmayı içermektedir. Meinong bu farka şu cümlelerle işaret etmektedir:

\begin{abstract}
"Şüphesiz, metafizik var olan [exists] her şeyle ilgilidir. Ancak, var olmuş ve var olacaklar da dahil olmak üzere var olanların [exists] bütünü, bilgi nesnelerinin bütününe kıyasla sonsuz küçüktür.”³
\end{abstract}

Nesneler kuramı, varlık sahibi olanların yanı sıra varlık-dışı olanları da kuşatan bir disiplin olarak ortaya konmaktadır. Kuramın amacı, dünyanın özelliklerini ve nelerden oluştuğunu, tamlığı ve nihai temellerini saptayacak biçimde anlamaktır. ${ }^{44}$ Meinong'un izlediği yöntem ise varlık sahibi olsun veya olmasın, bütün nesnelerde bulunan verili olanın incelenmesidir. ${ }^{45}$ Buna ek olarak dilsel olguların incelenmesi, kuramın araçlarından biri olarak görülmektedir. ${ }^{46}$

Meinong, varlı̆̆ı, (being, Sein) uzam-zamansal olarak var olan (existence, Existenz) ve uzamzamansal olarak var diyemeyeceğimiz ama bir biçimde varlık sahibi, kalıcılıkları (subsistence, Bestand) olan nesneler şeklinde ikiye ayırmaktadır. ${ }^{47}$ İlk grupta, "ağaç”, "masa” gibi fiziksel nesneler vardır. "Kuzeyde olmak" veya "benzerlik" gibi nesneler ikinci gruba örnektir. ${ }^{48}$ Meinong’a göre

40 Bu düşünürlerin yanı sıra Epikürcülük, İbn-i Sina, Thomas Aquinas ve Descartes gibi düşünürler de benzer düşünceleri tartışmaktadır. Kenneth J. Perszyk, Nonexistent Objects: Meinong and Contemporary Philosophy, (Springer, 1993), 68-79.

41 Detaylı inceleme için bkz.: Perszyk, Nonexistent Objects: Meinong and Contemporary Philosophy, 68-79. Ayrıca bkz.: Ekren, "Alexius Von Meinong ve Nesneler Teorisi", 12-14.

42 Carolyn Swanson, Reburial of Nonexistents: Reconsidering the Meinong-Russell Debate, 8. Düşünülebilir her şeyin nesne olması aynı zamanda bilginin konusu olabilmeleri anlamına gelmektedir. Dolayısıla, "yuvarlak kare", "uçan at" gibi nesneler de hakkında bilgi edinilebilir nesneler olmaktadır. Bkz.: Swanson, Reburial of Nonexistents: Reconsidering the Meinong-Russell Debate, 8-9.

43 Alexius Meinong, "Theory of Objects”, 79. Meinong’a göre varlık-dışı nesneler üzerine inceleme yapmayan geleneksel metafizik, "aktüel olandan yana önyargıya" sahip bir disiplindir. Kendi kuramı böylesi bir önyargıyı taşımamaktadır. Meinong, “Theory of Objects”, 78-81.

44 Meinong, "Theory of Objects", 78.

45 Perszyk, Nonexistent Objects: Meinong and Contemporary Philosophy, 11. Verili olanlar hem deneysel bilimlerin hem de Meinong'un kuramının hareket noktası olarak düşünülmektedir. Bkz.: Johann, Marek, "Alexius Meinong”, içinde The Stanford Encyclopedia of Philosophy, ed. Edward N. Zalta, (Metaphysics Research Lab, Stanford University, Spring 2019), erişim 14.12.2020, https://plato.stanford.edu./archives/spr2019/entries/meinong/. Russell, Meinong'un bu tavrında yer alan deneysel temelde düşünmeyi takdir etmektedir. Russell, "Meinong's Theory of Complexes and Assumptions (I.)”, 205.

46 Meinong, dilsel olgularla Russell gibi mantıksal bir dilden söz etmemektedir. Meinong, "Theory of Objects”, 103. Daha önce ifade edildiği üzere, Russell'ın dilsel incelemesi betimlemeler kuramı yoluyla çözümleme yaparak mantıksal biçimi açı̆̆a çıkarmak üzerinedir.

47 Smith, "The Russell-Meinong Debate”, 307. Meinong, var olan nesneleri gerçek (real), kalıcı olan nesneleri ideal (ideal) nesne olarak adlandırmaktadır. Russell, bu ayrımın kendi var olma-kalıcı olma ayrımına denk düştüğünü belirtmektedir. Linsky, "Russell's Notes for Meinong's Theory of Complexes and Assumptions", 151. Ayrica bkz.: Chisholm, "Beyond Being and Nonbeing", 246.

48 Matematiksel nesneler ve önermeler yine bu grupta düşünülmektedir. Meinong, "Theory of Objects”, 80. Bu durum, Meinong ile Russell'ın uzlaştığı bir durumdur. 
doğru önermeler de kalıcılıkları olan nesneler olarak varlık sahibidir. ${ }^{49}$ Bu nesnelerin yanı sıra ne var olan ne de kalıcı olan varlık-dışı (non-being, Nichtsein) nesneler ${ }^{50}$ vardır. Bu gruptaki "altın dağ", "uçan at" gibi nesneler, deneyden hareketle varlık-dışı nesne olarak düşünülmekteyken "yuvarlak kare” gibi nesneler, mantıktan hareketle varlık-dışı nesne olarak düşünülmektedir. ${ }^{51}$

Meinong'un kuramında varlık-dışı nesnelerin varlık sahibi olduğu düşüncesi tartışmalıdır. Meinong, bu türden nesnelerin var olduğu üçüncü bir alan olduğu görüşünü inceleyip reddetmektedir. ${ }^{52}$ Olanaklı bir argüman şu şekilde ilerlemektedir ${ }^{53}$ : "Yuvarlak kare, yuvarlaktır" önermesi doğru bir önerme olarak kalıcılık sahibidir. Önermeler bütün-parça ilişkisine sahip olduğu için, bütün olan önerme varlık sahibiyse parçaları da varlık sahibi olmalıdır. Bu durumda, önermenin parçalarından olan "yuvarlak kare” nesnesi varlık sahibi olmalıdır. Bu varlık ne var olma ne de kalıcılık sahibi olma olabilir. Dolayısıyla, varlık-dışı nesnelerin kendilerine ait varlık alanı vardır. Ancak Meinong’a göre; önermeler, bütün-parça ilişkisi taşımadıkları için önermenin varlık sahibi olması parçalarına ilişkin bir çıkarım yapmaya izin vermemektedir. ${ }^{54}$ Dolayısıyla, varlıkdışı nesnelere ait üçüncü bir varlık alanı yoktur. Bu türden nesneler "varlık ve varlık-dışı olmanın ötesinde (beyond being and non-being, jenseits von Sein und Nichtsein) ${ }^{55}$ olan nesnelerdir.

Nesnelerin ayrıma tabi tutulduğu bir diğer durum tamlıklarıdır. Meinong var olan ve kalıcılığı olan nesneleri tam, bu nedenle de belirli nesneler olarak ele almaktadır. ${ }^{56} \mathrm{Ne}$ var olan ne de kalıcı olan nesnelerden çelişkisiz olanlar tam veya eksik olabilirken çelişkili olanlar ise eksik nesnelerdir. ${ }^{57} \mathrm{Bu}$ kategorinin son çeşidi olan, nesnelerin varlığa göre belirlenmemiş olanları da yine eksik nesnelerdir. ${ }^{58}$ Meinong'un nesneler bölümlemesi Marek’e göre aşağıdaki tabloyla gösterilebilir ${ }^{59}$ :

49 Meinong, Russell’ın iddia ettiğinin aksine, yanlış önermelerin kalıcılıkları olduğu düşüncesinde değildir. Ona göre, yargıların doğruluk değerleri doğrudan nesnelleri olup olmamasına bağlıdır; eğer bir yargı doğruysa, yargının gönderimi olan kalıcı bir nesnel olmalıdır. Bkz.: Meinong, "Theory of Objects", 90.

50 Smith, "The Russell-Meinong Debate", 307. Meinong'un bu türden var olanları nesne olarak düşünmesinin arkasında dilsel bir gerekçe vardır. Ona göre, "x, yoktur" diyebilmek için bir "x" var olanından söz etmek gerekmektedir. Bkz.: Perszyk, Nonexistent Objects: Meinong and Contemporary Philosophy, 50.

51 Denkel, Yönletim-Dil Felsefesinde Bir Konu, 7.

52 Meinong, "Theory of Objects", 84-86.

53 Perszyk, Nonexistent Objects: Meinong and Contemporary Philosophy, 55-56.

54 Meinong, “Theory of Objects”, 85. Göründügü üzere, Meinong, Russell'ın aksine önermeleri bütün-parça ilişkisi içinde düşünmemektedir. Bu görüş, nesne kuramının temel ilkelerinden olan "Bağımsızlık İlkesi” yoluyla desteklenmektedir. Bu ilkeler ileride detaylıca açılacaktır. Diğer yandan, varlık-dışı nesnelerin özne yerinde durduğu önermelerde aslında gerçek bir özne olmadıkları düşüncesi iki düşünürün ortaklaştığı bir düşüncedir. Bkz: Perszyk, Nonexistent Objects: Meinong and Contemporary Philosophy, 58.

55 Meinong, "Theory of Objects", 86.

56 Swanson, Reburial of Nonexistents: Reconsidering the Meinong-Russell Debate, 16.

57 Perszyk, Nonexistent Objects: Meinong and Contemporary Philosophy, 110. Örneğin, "altın dağ" olanaklı ama deneyimde karşılığı olmayan eksik bir nesnedir. "Yuvarlak kare” ise çelişkili olduğu için olanaksız ve eksik bir nesnedir.

58 Swanson, Reburial of Nonexistents: Reconsidering the Meinong-Russell Debate, 23. Bu nesneler, "altın dağ", "yuvarlak kare” türünden nesnelere benzer olarak varlık sahibi değildir. Ancak "altın dağ", "yuvarlak kare” gibi eksik nesnelerden farkları ise varlık-dışı dahi olmamalarıdır, varlığa göre belirlenememeleridir. 


\begin{tabular}{|c|c|c|c|c|c|}
\hline \multicolumn{6}{|c|}{$\begin{array}{c}\text { NESNELER } \\
\text { [Her şey] }\end{array}$} \\
\hline \multicolumn{2}{|c|}{ Varlık [Being] Sahibi Nesneler } & \multicolumn{4}{|c|}{ Varlık [Being] Sahibi Olmayan Nesneler } \\
\hline $\begin{array}{c}\text { Gerçek } \\
\text { Nesneler (Var } \\
\text { olan [exists] } \\
\text { ve aynı za- } \\
\text { manda kalıcık } \\
\text { [subsists] } \\
\text { taşıyanlar) }\end{array}$ & $\begin{array}{c}\text { İdeal Nesneler } \\
\text { (Yalnızca kalıcılık } \\
\text { taşıyanlar) }\end{array}$ & \multicolumn{3}{|c|}{ Varlık-Dışı [Non-Being] Nesneler } & $\begin{array}{l}\text { Varlığa Göre Belirlen- } \\
\text { memiş Olan Nesneler }\end{array}$ \\
\hline$\downarrow$ & $\downarrow$ & \multicolumn{2}{|c|}{ Çelişkisiz Nesneler } & Çelişkili Nesneler & $\downarrow$ \\
\hline $\begin{array}{c}\text { Tam nesneler: } \\
\text { Örneğin; tatlı } \\
\text { çörekler (me- } \\
\text { sela önüm- } \\
\text { deki masanın } \\
\text { üzerinde } \\
\text { duranlardan } \\
\text { biri), ... ma- } \\
\text { salar, yıldızlar, } \\
\text { vs., ... }\end{array}$ & $\begin{array}{l}\text { Tam nesneler: Örne- } \\
\text { ğin; tatlı çöreğimin } \\
\text { masanın üzerinde ol- } \\
\text { ması önermesi (veya } \\
\text { olgu durumu }{ }^{60} \text { ), } \\
\text { tatlı çöreğimin buz } \\
\text { dolabından olmaması } \\
\text { durumu, önümdeki } \\
\text { tatlı çöreklerin sayısı }\end{array}$ & $\begin{array}{c}\text { Tam nesne- } \\
\text { ler: Örneğin; } \\
\text { çikolatadan } \\
\text { değil de } \\
\text { vanilyadan } \\
\text { yapılmış, } \\
\text { masanın } \\
\text { üzerinde } \\
\text { duran tatlı } \\
\text { çörek, tatlı } \\
\text { çöreğimin } \\
\text { buzdolabında } \\
\text { olması duru- } \\
\text { mu, ... }\end{array}$ & $\begin{array}{l}\text { Var Olmayışı } \\
\text { “açıç̧a varsa- } \\
\text { yılan” Eksik } \\
\text { nesneler: } \\
\text { Örneğin; tatlı } \\
\text { çöreklerden } \\
\text { yapılmış dağ, } \\
\text { altın dağ, ... }\end{array}$ & $\begin{array}{c}\text { Tam veya Eksik } \\
\text { Nesneler: Örneğin; } \\
\text {.., en büyük asal } \\
\text { sayı, yuvarlak kare, } \\
\text { tüm kümelerin } \\
\text { kümesi, ... }\end{array}$ & $\begin{array}{c}\text { Çelişkili Olarak } \\
\text { Belirlenmeyen ve } \\
\text { Var-Olmayışı "açıça } \\
\text { varsayılmayan” Eksik } \\
\text { nesneler: Örneğin; } \\
\text { şöylesi çörek, ..., tek } \\
\text { özelliği mavi olmak } \\
\text { olan nesne, ... }\end{array}$ \\
\hline
\end{tabular}

Meinong mantık ilkelerinin uygulanabilir olduğu nesneleri de birbirinden ayırmaktadır. Ona göre çelişmezlik ilkesi yalnızca var olan ve kalıcı olan nesnelere uygulanabilmektedir. 3.halin olanaksızlığı ilkesi ise yalnızca eksik nesneler için geçerli olmamaktadır. Örneğin yuvarlak kare nesnesi yakışıklı olma özelliğine göre belirli olmadığ ${ }^{61}$ için "yuvarlak kare yakışıklıdır” ve "yuvarlak kare yakışıklı değildir” önermelerinden birisinin doğru olması zorunlu değildir. ${ }^{62}$

60 Olgu durumları ifadesi, "state of affairs (Sachverhalt)" sözcüklerine karşılık olarak tercih edilmiştir. Burada görüldüğü gibi, olgu durumları ile nesnellerin bir ve aynı var olan olduğu düşünülebilmektedir. Simons, Meinong’un bu düşünceyi reddettiğini aktarmaktadır. Ona göre; "Nesneller, tıpkı Russell'ın önermeleri gibi, ne doğruluk ve yanlışlığın soyut taşıyıcısı olarak modern (Bolzano-Frege) anlamdaki önermelerdir ne de önermeleri doğru veya yanlış yapma anlamında olgulardır. Nesneller hem doğruluk taşıma hem de doğru kılma görevini aynı anda üstlenmeye çalışılar." Simons, Philosophy and Logic in Central Europe from Bolzano to Tarski, 164.

61 Bu belirsizlik her şeyi bilen, kusursuz bir kavrayış için dahi geçerlidir. Diğer bir deyişle, ortada belirlenebilecek bir şey yoktur. Swanson, Reburial of Nonexistents: Reconsidering the Meinong-Russell Debate, 17.

62 Bu noktada, var olan veya kalıcı olan çeşitli nesneler için de benzer örnekler verilebileceği düşünülebilir. Örneğin "3 sayısı" da "yakışıklı olmak” özelliğine karşı belirli değildir. Fakat Meinong’a görüşü uyarınca matematiksel nesneler kalıcılık sahibi nesneler olarak tam nesneler olmalıdır. Swanson’a göre Meinong bu sorunu özelliklerin uygulanabilirlik alanını tanımlayarak çözmektedir. "3 sayısı” yalnızca sayısal özellikler bağlamında belirlenebilir olduğundan bu nesne, bu özellikler alanı içinde 3.halin olanaksızlığı ilkesine tabi olmaktadır. Swanson, Reburial of Nonexistents: Reconsidering the Meinong-Russell Debate, 18, 21. 
Meinong'un nesneler kuramı çeşitli ilkeler öne sürmektedir. Bunlardan ilki "Bağımsızlık İlkesi” ${ }^{63}$ olarak adlandırılmaktadır. Bu ilke, bir nesnenin varlık (being, Sein) sahibi olmaksızın özelliklere (property, Sosein) sahip olabileceğini bildirmektedir. Meinong bu ilkeyi "Bazı var olmayan nesnelerin var oldukları doğrudur" cümlesiyle ifade etmektedir. ${ }^{64}$ Böylece ne var olan ne de kalıcı olan nesneler hakkında olan önermeler doğru değerini alabilmektedir. Örneğin, "Yuvarlak kare yuvarlaktır” önermesi, "yuvarlak kare” nesnesinin var olmasına zorunlu olarak koşullu olmadığı ve "yuvarlak kare” nesnesinin bir özelliği olan "yuvarlaklığını" bildirdiği için doğru olmaktadır.

İkinci ilke "Kayıtsızlı İlkesi" adıyla sunulmaktadır ve nesnelerin özelliklerinin nesnenin varlığına veya var olmayışına kayıtsız olduğunu bildirmektedir. ${ }^{65} \mathrm{Bu}$ bağlamda Meinong özellikleri de birbirlerinden ayırmaktadır. Ona göre iki tür özellik vardır; bunlar nükleer özellikler ve ekstra-nükleer özelliklerdir. ${ }^{66}$ Bunların ilki ${ }^{67}$ kaplamsal özelliklerdir; nesnenin doğasına ait, özsel, birincil özelliklerdir. İkincisi ${ }^{68}$, içlemsel özelliklerdir; bu özellikler, nesnenin doğasına ait değillerdir. Varlık yükleminin nereye konumlanacağı sorusu, Kayıtsızlık İlkesinin aslında varlık fiilinin gerçek bir yüklem ${ }^{69}$ olup olmadığını tartıştığını göstermektedir.

Meinong'un varlığı gerçek bir yüklem olarak görüp görmediği konusu tartışmalıdır. ${ }^{70}$ Kayıtsızlık ilkesi gereği, varlık ile özelliklerin aynı düzeyde düşünülmediği açıktır. Ancak, buradan varlığın bir yüklem olarak düşünülmediği sonucu zorunlu olarak çıkmamaktadır. Nitekim Routley ve Griffin’e göre, Meinong varlığı bir yüklem olarak düşünmektedir ancak bu yüklem, nesnenin doğasını betimleyen bir yüklem değildir. ${ }^{71}$ Perszyk bu görüşü "sağlam formülasyon (strong formulation)" olarak adlandırmaktadır fakat ona göre bu görüşe karşıt

63 Bu ilke Meinong'un öğrencisi Ernst Mally (1879-1944) tarafından formüle edilmiştir. İlkenin ontolojik ve semantik olarak iki biçimi vardır. Ontolojik olan, bir nesnenin, özelliklerinin varlığından bağımsız olduğunu belirtmektedir. Semantik olan, “a, F’tir” cümlesinin, “a’nın varlık sahibi olduğu yanlıştır” cümlesine rağmen doğru olabileceğini belirtmektedir. Bkz.: Perszyk: Nonexistent Objects: Meinong and Contemporary Philosophy, 40. Chisholm’a göre bu ilke, varlık-dışı nesnelerin üçüncü bir varlık alanında düşünülmemesinin derli toplu ifade edilmesidir. Chisholm, "Beyond Being and Nonbeing", 245.

64 Meinong, "Theory of Objects", 83.

65 Perszyk, Nonexistent Objects: Meinong and Contemporary Philosophy, 44.

66 Perszyk, Nonexistent Objects: Meinong and Contemporary Philosophy, 44-45. Perszyk, bu adlandırmanın Findlay'e ait olduğunu, Terence Parsons'in ise bu özellikleri karakterize eden ve karakterize etmeyen özellikler olarak adlandırdığını aktarmaktadır. Ancak Perszyk'in aktardığına göre yorumcular Findlay’in adlandırmasını takip etmektedirler. Detaylı tartışma için bkz.: Perszyk, Nonexistent Objects: Meinong and Contemporary Philosophy, 82. Swanson'a göre ise bu ayrım netlik taşımamaktadır. Swanson, ekstra-nükleer özelliklerin Findlay tarafından yüksek düzey özellikler, Perszyk tarafından özsel özellikler olarak ele alındığını aktarmaktadır. Ona göre, Parsons ise bu özellikleri ontolojik, modal, yönelimsel ve teknik olarak bölümlemektedir. Detaylı inceleme için bkz.: Swanson, Reburial of Nonexistents: Reconsidering the Meinong-Russell Debate, 31-32.

67 "Uzun olmak", "konuşkan olmak” veya "acı olmak” gibi özellikler bu türden özelliklerdir.

68 Bu özellikler "var olmak”, "olanaklı olmak” gibi üst-düzey özelliklerdir.

69 Russell, benzer şekilde, var olmayı (existence) bireyler hakkında olmayan, sınıflar hakkında olan ikinci düzey bir yüklem olarak düşünmektedir. Simons, Philosophy and Logic in Central Europe from Bolzano to Tarski, 174.

70 Varlığın yalnızca uzam-zamansal olarak var olanlara uygulanabileceği düşüncesi Meinong'un öğrencisi Rudolf Ameseder'in (1877-1934) ilkeleştirdiği bir düşüncedir. Meinong'un bu düşünceyi kabul edip etmediği şüphelidir. Bkz.: Smith, The Russell-Meinong Debate”, 322.

71 Griffin, "Russell's Critique of Meinong's Theory of Objects", 387-388. 
olan zayıf formülasyon (weak formulation) vardır; bu görüş, varlığın bir yüklem olmadığını, sadece ekstra-nükleer özellik olabileceğini öne sürmektedir. ${ }^{72}$

Meinong, bağlantılı olarak, var olma (exist, Existiert) ile mevcut (is existent, Existierend sein) arasında da ayrım yapmaktadır. ${ }^{73}$ İlki uzam-zamansal, fiziksel olarak var olma anlamına gelirken ikincisi böylesi bir gerekliliği taşımamaktadır. Böylece "mevcut yuvarlak kare" veya "mevcut Fransa kralı" fiziksel olarak var olmamasına rağmen mevcut olarak ele alınmaktadır. ${ }^{74}$

Meinong'un nesneler kuramı, değilleme (negation) işlemini kapsamlı (wider) ve sınırlı (narrow) olmak üzere iki farklı şekilde yapmaktadır ${ }^{75}$ Kapsamlı değilleme, bütün önermeyi değillerken sınırlı değilleme ise yalnızca yüklemi değillemektedir. Örneğin;

(7) "Yuvarlak kare, yuvarlaktır" önermesi kapsamlı değillendiği zaman;

(8) "Yuvarlak kare, yuvarlak olma özelliğine sahip değildir."76 elde edilir. Sınırlı değillendiği zaman;

(9) "Yuvarlak kare, yuvarlak olmama özelliğine sahiptir."77 elde edilir.

(8) ve (9) arasında ayrım yapmak ${ }^{78}$ Russell'ın (4)'ü değilleyerek (5)'i elde etmesinin önüne geçmektedir. Dolayısıyla, Meinong, Russell'ın öne sürdüğü gibi çelişmezlik ilkesini çiğnememektedir. Diğer yandan, varlık-dışı nesnelerin çeşitli özelliklere göre belirsiz olması nedeniyle 3.halin olanaksızlığı ilkesinin çiğnendiği eleştirisi de cevaplanmaktadır.

Meinong, Russell'ın sayılabilirlik eleştirisine de cevap vermektedir. Ona göre, Russell'ın düşündüğünün aksine, varlık-dışı nesneleri sayabilmek olanaklıdır. ${ }^{79}$ Russell'ın nesne olmak koşulu olarak verdiği özdeşlik koşulunu Meinong, "tüm kaplamsal özelliklere göre ayırt edilemez olmak" biçiminde vermektedir. ${ }^{80}$ Böylece bir özdeşlik koşulu verilerek sayılabilirlik olanaklı kılınmaktadır.

72 Persyzk, Nonexistent Objects: Meinong and Contemporary Philosophy, 51-54.

73 Perszyk, Nonexistent Objects: Meinong and Contemporary Philosophy, 235. Ayrica bkz.: Griffin, "Russell's Critique of Meinong's Theory of Objects", 388-390.

74 Russell, 1906'da yazdığı mektupta bu ayrımı gerçek bir ayrım olarak bulmadığını belirtmektedir. Smith, "The Russell-Meinong Debate", 349. Ayrıca, Meinong ve öğrencilerinin metinlerinde oluşan, Untersuchungen zur Gegenstandstheorie und Psychologie adlı metnin incelemesinde, "mevcut yuvarlak kare" nesnesinin mevcut, yuvarlak ve kare olan bir nesneyi imlediği düşüncesinin hatalı bir şekilde, mevcut sıfatını taşıyan bütün deyimlerin varlık sahibi görülmesi sonucuna neden olduğunu ifade etmektedir. Öyle ki, bu yaklaşımla, ontolojik argüman dahi geçerlilik kazanmaktadır zira "mevcut tanrı" deyiminin tanrı olan ve mevcut olan bir nesneye gönderim yapması gerekmektedir. Russell, "Review of Meinong and Others, Untersuchungen zur Gegenstandstheorie und Psychologie”, 599.

75 Griffin, "Russell's Critique of Meinong's Theory of Objects", 392-393. Ayrica bkz.: Simons, Philosophy and Logic in Central Europe from Bolzano to Tarski, 182. Smith, "The Russell-Meinong Debate”, 329.

76 Mantıksal gösterimiyle: $\neg \exists x(Y x K x \wedge Y x)$

77 Mantıksal gösterimiyle: $\exists x(Y x K x \wedge \neg Y x)$

$78 \mathrm{Bu}$ ayrım aracılığıyla "karşıt özelliğin varlığı (not-so-being, Nichtsosein) ile "özelliğin yokluğu (not-being-of-aso-being, Nichtsein eines Soseins) arasında bir ayrım gözetilmiş olmaktadır. Bkz.: Griffin, "Russell’s Critique of Meinong's Theory of Objects", 392-393.

79 Smith, "The Russell-Meinong Debate", 319-320.

80 Griffin, "Russell's Critique of Meinong's Theory of Objects”, 395. 
Meinong'un nesne kuramı, Russell'ın ontolojisinden farklı olarak, mantık temelli bir kuram değildir. Aksine, mantık belirleyici değil yalnızca nesne kuramı ile uyumlu olarak düşünülmektedir. Dolayısıyla, bu kuram mantıkla çatışan bir kuram değildir. Meinong, temel olarak, dünyada özelliklerin olduğunu düşünmektedir. Uzam-zamansal olarak var olanlar, bu özelliklerin demeti olarak düşünülmektedir. Ancak bu özelliklerin bir araya getirilişi her zaman var olmak veya kalıcı olmak durumunda değildir. Bu kurama göre, "altın olma” ve "dağ olma” özelliklerinin bir araya getirilmesiyle düşünülebilir olan, altın dağ gibi deneyimde olmayan ancak olabilecek nesnelerden söz edilebilir. Benzer şekilde "yuvarlak olma" ve "kare olma” özellikleri bir araya getirilerek düşünülebilir olan ancak içsel çelişki taşıması nedeniyle olanaksız olan nesnelerden söz etmek olanaklıdır. Bu noktada, özellik ile varlık arasında bağımsızlık olduğu öne sürülerek varlığın, birincil düzey yüklem olmadığı ifade edilmektedir. Özelliklerin bildirilmesiyle oluşan nesneller (veya önermeler) ile özellikler arasında da yine bağlayıcı bir ilişki yoktur. Söz gelimi "kırmızı araba", kırmızı ve araba olan bir nesneyi imlerken "araba kırmızıdır", arabanın kırmızı olması durumunu imlemektedir. Meinong'un yaptığı, bu iki durumu birbirinden ayırt etmektir. Önermelerin bütün-parça ilişkisi içinde düşünülmemesi bu ayrımı olanaklı kılmaktadır. O halde, Meinong’a göre dünya özellikler ve nesnellerden oluşmaktadır. Düşünülebilen her şey nesnedir ancak nesneler arasında varlık tarzları açısında farklılıklar vardır. Mantık ilkeleri bu farklılıklar bağlamında iş görmelidir. Mantık ve metafizik bu bağlamda nesne kuramının alt disiplinleri olarak ele alınmalıdır.

\section{Değerlendirme}

Russell'ın Meinong ile tartışmasında öne sürdüğ̈̈ ${ }^{81}$ itirazlar Smith'e göre şu şekilde özetlenebilir ${ }^{82}$ :

(a) "Varlık-dışı nesnelerin çelişmezlik yasasını "tahammül edilemez" şekilde çiğnemesi.

(b) Bazı varlık-dışı nesnelerde içerilen hatalı var olma [existence] görüşleri ve örtük ontolojik argüman.

(c) Nesneleri tanımlamak için gerekli olan modal kavramların reddedilmesi.

(d) Varlık-dışı nesnelerin 3.halin olanaksızlı̆̆ını çiğnemesi.

(e) Meinong'un görüşlerinden hareketle bazı cümleler için doğruluk değerlerinde hatalar olmass.

(f) Russell'ın, gönderim deyimlerinin önermelerin gerçek mantıksal özneleri olmadığını, Meinong'un önermeleri hatalı bir şekilde özne-yüklem mantıksal biçiminde düşündüğünü ve bu yüzden hatalı bir şekilde "yuvarlak kare” gibi deyimlerin varlık-dışı nesnelere gönderim yaptığını düşündüğünü ileri sürmesi.

81 Russell-Meinong tartışmasının daha yoğun olduğu dönemler 1906-7 yıllarına kadardır. Russell bu dönemden sonra çeşitli görüş değişikliklerine gitmiştir. Makalenin bağlamı dışında olduğu için bu değişikliklere değinilmeyecektir.

82 Smith, "The Russell-Meinong Debate", 311-312. 
(g) Russell'ın, kendi betimlemeler kuramının genelde Meinong'un kuramından üstün ve daha verimli bir mantıksal çözümleme önerdiğini iddia etmesi.

(h) Russell'ın, ...var olmayan nesneleri kabul etmenin, mantığın her zaman gözetmesi gereken gerçeklik hissinden ${ }^{83}$ yani dikkati aktüel dünyaya vermekten kopmak olduğunu iddia etmesi."

Smith'e göre, Meinong'un nesneler kuramının pek çok argümana cevabı olduğu açıktır ${ }^{84}$ : Öncelikle, Meinong'a göre de var olan ve kalıcılığı olan nesneler çelişmezlik ilkesine tabidir. Meinong yalnızca var olmayan nesnelere bu ilkenin uygulanamayacağını düşünmektedir. (b)'de öne sürülen varlığın hatalı bir şekilde yüklem olarak ele alınması eleştirisi Meinong’un yanlış anlaşıldığını göstermektedir. Meinong’un görüşleri açık olmasa da Kayıtsızlık İlkesiyle varlık ve nükleer özellikler arasında düzey farkı gözetildiği açıktır. (d) ile öne sürülen 3.halin olanaksızlı̆̆ ilkesinin çiğnenmesi eleştirisi Meinong’un nesne kuramı bağlamında yerinde bir eleştiri olarak görünmemektedir zira Meinong eksik nesnelerin çeşitli yüklemlere göre belirli olmadığını düşünmektedir. Dolayısıyla, bu ilke, bu türden nesnelere uygulanamamaktadır. Meinong'un Bağımsızlık İlkesi özelliklerin varlıktan bağımsız olduğunu öne sürerek var olmayan nesneler hakkında olan önermelerin nasıl doğru değerini alabileceğini göstermektedir. Bu nedenle, (e)'de öne sürülen eleştiri Meinong’un kuramına yönelik içeriden değil, dışarıdan bir eleştiri olmaktadır. Diğer bir deyişle, düşünürlerin vardıkları sonuçlar arasındaki fark, varsaydıkları ilkeler arasındaki farktan ileri gelmektedir. (c)'nin konu ettiği modal kavramların nesne tanımlamadaki yeri konusunda iki düşünür birbirinden ayrılmaktadır. Meinong'un aktüel, olanaklı ve olanaksız nesneler ayrımı yapması, bu kavramlara nesne kuramında zorunlu olarak yer vermesine neden olmaktadır. Meinong’a göre de varlık-dışı nesneler önermelerde gerçekten özne olarak durmadığı için (f) ile öne sürülen eleştiri yine tam olarak yerini bulamamaktadır.

Son olarak, (h) ile ortaya konan "gerçeklik hissinden kopuş" nitelemesinin hangi düşünür için daha uygun olduğunu inceleyelim. Göründüğü üzere, Russell nesne kuramını mantığın doğrulukları, ilkeleri zemininde ortaya koymaktadır. Diğer bir deyişle, mantığın belirlediği bir ontoloji önermektedir. Meinong ise mantıktan değil gramerden yola çıkan, nesne kuramının ilkelerinin ontolojiyi belirlediği, mantık ilkelerinin de bu bağlamda ele alındığı fakat asla reddedilmediği bir kuram önermektedir. Bu noktada, Russell aktüel olandan yana olmasını gerçeklik hissine sahip olmak olarak görse de Meinong için bu durum bir önyargı olarak nitelendirilmektedir. Önyargılı olmaktan gerçeklik hissine daha fazla sahip olmak sonucunun zorunlu olarak çıkmadığı açıkça ortadadır. Ayrıca, "yuvarlak kare, yuvarlaktır” önermesine Russell'ın yanlış, Meinong’un doğru değerini atadığı düşünülürse, Meinong’un sağduyuya daha yakın bir noktadan düşünce geliştirdiği görünür olmaktadır. ${ }^{85}$ Buradan hareketle, Russell ile

83 Russell bu durumu "gerçeklik içgüdüsü eksikliği" ifadesiyle betimlemektedir. Bertrand Russell, The Philosophy of Logical Atomism, (Routledge, London and New York, Taylor \& Francis e-Library, 2009), 55.

84 Smith, "The Russell-Meinong Debate”, 312.

85 Simons benzer bir düşüncenin Routley tarafından ileri sürüldüğünü aktarmaktadır. Bkz.: Simons, Philosophy and Logic in Central Europe from Bolzano to Tarski, 186. Arda Denkel, yine benzer bir düşüncenin Strawson tarafindan öne sürüldüğünü aktarmaktadır. Bkz.: Denkel, Yönletim-Dil Felsefesinde Bir Konu, 24. 
Meinong tartışmasında Russell'ın duyulurlardan, Meinong'un ise düşünülürlerden yana tavır

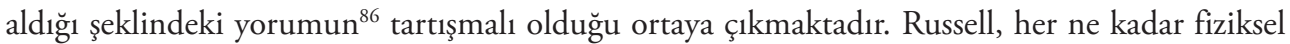
var olanları temele alan bir ontoloji önerse de onun bu tartışmada, kalıcılı̆̆ı olan nesneleri ontolojisine kabul ettiğine, hem doğru hem de yanlış önermelerin zihin-dışı gerçeklikleri olduğunu iddia ettiğine ve tüm kuramını mantık zemininde inşa ettiğine dikkat etmek gerekmektedir. Dolayısıyla, Russell'ın düşünülürlerden yana bir tavırda olduğunu söylemek daha olasıdır. Bu, Meinong tartışmada duyulurlardan yana tavır aldığını söylemek değildir. Aksine, Meinong'un kuramı böyle bir ayrıma kayıtsızdır. Meinong' ın kuramında, yalnızca aktüel olanları inceleyen metafiziğin nesne kuramı içinde çok küçük bir yer tutuyor olması, onun duyulurdüşünülür ayrımı bağlamında daha kuşatıcı bir tavır gözettiğini göstermektedir. Ayrıca dilsel olguların inceleme aracı olarak görülmesi yine mantıksal zemindense sağduyuya daha yakın bir pozisyon alındığına işaret etmektedir.

İki düşünür, bu tartışmada ortaya çıkan tüm farklı düşüncelere rağmen genel anlamda benzer düşünceleri paylaşmaktadırlar. Bu benzerlikler; zihin-dışı gerçekliğin fiziksel, kalıcı ve önerme düzeyindeki nesneler bağlamında kabul edilmesi, buna bağlı olarak matematiksel nesnelerin ve tümellerin ontolojide aynı yerde konumlandırılması, nesnelere doğrudan gönderim yapılıyor olması ve varlık-dışı nesnelerin dilsel ifadelerinin önermelerde gerçek bir özne olarak yer alamıyor olması olarak sıralanabilir.

Russell-Meinong tartışmasının yeniden ele alınmasının bir nedeni, Quine’ın ontolojik tartışmaları yeniden felsefenin gündemine getirmeyi başarması sonrasında "neler vardır", "nesne olmanın koşulları nelerdir" gibi metafizik soruların yeniden gür bir şekilde gündeme gelmesidir. ${ }^{87}$ Bir diğer neden, Strawson'un Russell'ın betimlemeler kuramına yönelttiği eleştiriler ile o zamana

86 Yavuz’un yorumu şu şekildedir: "Meinong ve Russell tartışmasının, indirgemeci bir tavırla, yine düşünülürler ve duyulurlar tartışmasına indirgenmesi mümkündür. Böyle bir indirgemede Meinong düşünülürleri temsil ederken Russell duyulurlar lehine olacak şekilde kendi fikirlerini savunur." Yavuz, "Varolmayan Nesneler Semantiği”, 126-127.

87 Quine'ın "On What There Is" başlıklı makalesi, geçtiğimiz yüzyılın ikinci yarısında metafiziğin geri dönmesinin miladı olarak düşünülmektedir. Bkz.: Franceso Berto ve Matteo Plebani, Ontology and Metaontology: A Contemporary Guide, (Bloomsbury Academic, 2015), 1. Ayrıca bkz.: Robert C. Koons ve Timothy H. Pickavance, Metaphysics: The Fundamentals, (Wiley-Blackwell, 2014), 7. Benzer bir değerlendirme için yine bkz.: Dean W. Zimmerman, "Prologue: Metaphysics After the Twentieth Century", Oxford Studies in Metaphysics 1, (2004), 14. Kuşcu'nun yorumuna göre de ontolojiye geri dönüşte Quine’ın belirleyici bir etkisi vardır. Ona göre, analitik felsefe zaten başından beri ontolojik tartışmaları gözeten bir karaktere sahiptir, Quine’ın yaptığı ise yalnızca bu karakteri saygıdeğer biçimde yeniden merkezi bir rol sahibi kılmaktır. Egemen S. Kuşcu, "Analitik Felsefe: Dile Dönüşten Ontolojiye Dönüşe”, Kutadgubilig Felsefe-Bilim Araştırmalar 31 (Eylül 2016), 136. Quine, bir nesnenin ontolojiye kabul edilme koşulunu ise özdeşlik koşulunun verilebilir olması ve betimlemeler kuramı yoluyla niceleme yapıldığında bağlı değişkeninin değer alabiliyor olması olarak belirtmektedir. Bkz.: W.V.O. Quine, "On What There Is", içinde Contemporary Readings in the Foundations of Metaphysics, ed. Stephen Laurence ve Cynthia Macdonald, (Blackwell, 1998): 32-45. Quine, böylece, öne sürdüğü ölçütler itibariyle Russellcı bir yöntem izlemektedir. Hatta Simons’a göre, betimlemeler kuramı eleştirilmeye başladıktan sonra sadece Quine gerçek bir Russellcı olarak kalmıştır. Detaylı inceleme için bkz.: Simons, Philosophy and Logic in Central Europe from Bolzano to Tarski, 187-188. 
dek pek sorgulanmayan bu yöntemin gözden geçirilmeye başlamasıdır. ${ }^{88}$ Modal mantığın ve ona bağlı olarak modal semantiğin yükselişe geçmesiyle modal kavramların, dolayısıyla da olanaklı nesnelerin tartışılmaya başlaması başka bir nedendir. ${ }^{89}$ Böylesi bir yeniden ele alma hem yeniRussellcı hem de yeni-Meinongçu düşüncelerin ortaya çıkmasına neden olmuştur. Yeni-Russellcı düşünce, doğrudan gönderimin olanağının ve tekil önermelerin varlığının savunulmasıyla öne çıkmaktadır. ${ }^{90}$ Yeni-Meinongçuluğun bir biçimi, mantık temelli olmayan, mantığı nesne kuramının ilkelerine göre belirleyen bir Meinong yorumuyla geliştirilmiştir. Bunun yanı sıra Meinong’un zaten mantık ilkelerini reddetmeden bir kuram önerdiğini düşünerek Meinongçu çizgide kalan ve çağdaş dönemde ortaya konan yeni mantıklarla uyumlu metafizik çalışmalar belirmiştir. ${ }^{91}$

\section{Sonuç}

Russell, İdealizmden Gerçekçi bir ontolojik görüşe geçtikten sonra ilgisini gerçekçi ontoloji öneren düşünürlere yöneltmiştir. Bunlardan birisi, Mind dergisine kitabı hakkında inceleme yazısı istenmesi nedeniyle Meinong olmuştur. Meinong'un ontolojik anlayışı Russell'ın ontolojisiyle çeşitli açılardan benzer çeşitli açılardan farklıdır.

Russell, 1905'te ortaya koyduğu betimlemeler kuramına kadar katı bir gerçekçi düşünce içindedir. Ona göre, var olanlar doğrudan dilde yer almaktadırlar. Bu nedenle, dilsel deyimlerin her biri ve yanlış önermeler, dil dışı gerçekliklere gönderim yapmaktadırlar. Russell hem bu sorunu çözmek hem de Meinong’un varlık dışı nesnelerini kabul eden ontolojisine eleştiri getirebilmek adına betimlemeler kuramını geliştirmiştir. Bu kuram ölçüsünde, önermeler parçalarına çözümlenerek onların altında yatan mantıksal biçimler açığa çıkarılmaktadır. Böylece, gönderim deyimi gibi duran ifadelerin aslında tek başlarına anlamlı olmadığı, gönderimi olmayan ifadeleri içeren önermelerin çelişmezlik ilkesini ve 3.halin olanaksızlı̆̆ ilkesini çiğnediği ve bu önermelerin doğruluk değerinin aslında yanlış olduğu tek tek gösterilmektedir. Russell bu noktadan hareketle, varlık-dışı nesneleri ontolojisinden elemektedir, yalnızca fiziksel nesnelere ve kalıcılıkları olan nesnelere varlık atfetmektedir.

Meinong'un nesneler kuramı kuşatıcı bir kuramdır. Geleneksel metafiziğin aksine yalnızca fiziksel var olanları değil aynı zamanda varlık-dışı nesneleri de içermektedir. Meinong’a göre

88 Peter Frederick Strawson'ın eleştirilerini sunduğu metin 1950 yılında yayımladı̆̆ı On Referring başlıklı makalesidir. Strawson, temel olarak, doğru ya da yanlış olmayıp anlamlı olan önermelerin de olabileceğini ve anlamın kullanım ile ilişkili düşünülmesi gerektiğini ileri sürmektedir. Bu eleştirilerin detaylı incelemesi için bkz.: Denkel, YönletimDil Felsefesinde Bir Konu, 21-24.

89 Simons, Philosophy and Logic in Central Europe from Bolzano to Tarski, 187-188.

90 Bu düşünce temel olarak, belirli bir tekilin doğrudan önermenin oluşturucusu olabildiğini savunmaktadır. Bu düşüncenin önde gelen filozofları David Kaplan, Nathan Salmın, John Perry, Robin Jeshion, Kent Bach olarak görünmektedir. Bkz.: Greg Fitch ve Michael Nelson, "Singular Propositions", içinde The Standord Encyclopedia of Philosophy, ed. Edward N. Zalta, (Metaphysics Research Lab, Stanford University, Spring 2018), erişim 14.12.2020, https://plato.stanford.edu/archives/spr2018/entries/propositions-singular/.

91 Yeni-Meinongçu düşünce için bkz.: Berto ve Plebani, Ontology and Metaontology: A Contemporary Guide, 101-102, 110-112. Richard Routley, Terence Parsons, Dale Jacquette, Edward Zalta gibi düşünürler, çeşitli farklar gözetmekle birlikte Meinongçu bir bakış açısından güncel metafizik kuramlar önermektedirler. Detaylı aktarım için bkz.: Simons, Philosophy and Logic in Central Europe from Bolzano to Tarski, 190-191. 
düşünülebilen, bilgi nesnesi olabilen her şey nesnedir. Ancak nesnelerin varlık tarzları farklılık arz etmektedir. Fiziksel olan nesneler var olma özelliğine sahiptir. Fiziksel olarak var olmayan ancak bir biçimde varlık sahibi olan nesneler kalıcı olma özelliğine sahiptir. Bunların yanı sıra varlık sahibi olmayan nesneler vardır. Bunlar, çelişkili olmayan ancak deneysel olarak varlık-dışı olan altın dağ ve çelişkili olduğu için olanaksız olan yuvarlak kare gibi nesnelerce örneklenmektedirler. Son olarak, varlığa göre hiçbir biçimde belirli olmayan şöyle şöyle araba, bir üçgen gibi nesneler söz konusudur. Bu nesneler hiçbir şekilde bilginin konusu olamamaktadırlar. Bu çerçevede, nesnelerin tabi oldukları mantık ilkeleri değişkendir. Olanaksız nesnelere çelişmezlik ilkesi, eksik nesnelere 3.halin olanaksızlığı ilkesi uygulanmamaktadır. Bu bağlam, Meinong’un öğrencileri tarafından açıkça serimlenen ilkeleri ortaya çıkarmaktadır. Bağımsızlık ilkesi, nesnelerin özelliklerinin varlıklarından bağımsız olduğunu öne sürmektedir. Kayıtsızlık ilkesi nesnelerin doğaları gereği varlığa veya varlık-dışı olmaya kayıtsız olduğunu söylemektedir.

Russell, Meinong'a içsel ve dışsal eleştiriler yöneltmiştir. Gösterildiği üzere, içsel eleştiriler, Meinong'un kuramı pek doğru anlaşılmadan yapılmaktadır. Dışsal eleştiriler ise farklı ilkeleri varsaymaktan ileri gelmektedir. Dolayısıyla Meinong'u doğrudan bağlayan eleştiriler değillerdir. Mantığın ontolojinin belirleyicisi olarak görülmesi bu varsayımlardan biridir. Russell'ın bu varsayımı, onu düşünülürlerden yana tavır alan bir düşünür olarak konumlamaya yeterli olmaktadır. Meinong'un kuramının, hem deneysel ve dilsel incelemeyi birlikte yürütmesi hem de nesne kuramının fiziksel, kalıcılık sahibi ve varlık-dışı nesneleri tümden içermesinden dolayı daha kuşatıcı bir tavır aldığı görülmektedir. Bu kuşatıcı tavrın onu sağduyuya daha yakın bir düşünür kıldığını söylemek dahi olanaklıdır.

Tartışma, yeni metafizik kuramlara olanak açmış olmasından dolayı da önemlidir. Tartışmanın yeniden ele alınmasında, metafiziğin Quine sonrasında felsefenin gündemine yeniden güçlü bir şekilde dönmesi, Russell'ın betimlemeler kuramının eleştirilemeye başlanması ve başta modal mantık olmak üzere yeni mantıkların geliştirilmesi etkili olmuştur. Böylece, doğrudan gönderimi ve tekil önermeleri savunan yeni-Russellcı kuramlar ile yeni mantıklar zemininde kuram öneren veya mantığı metafizik kurama belirleyici görmeyen, onunla uyumlu gören yeni-Meinongçu kuramlar ortaya çıkmıştır.

\footnotetext{
Hakem Değerlendirmesi: Dış bağımsız.

Çıkar Çatışması: Yazar çıkar çatışması bildirmemiş,ir.

Finansal Destek: Yazar bu çalışma için finansal destek almadığını beyan etmiştir.

Peer-review: Externally peer-reviewed.

Conflict of Interest: The author has no conflict of interest to declare.

Grant Support: The author declared that this study has received no financial support.
} 


\section{Kaynaklar / References}

Berto Francesco ve Pleabani Matteo. Ontology and Metaontology: A Contemporary Guide. Bloomsbury Academic, 2015.

Chisholm, Roderick M. "Beyond Being and Nonbeing”. Philosophical Studies 24 (4), (1973): 245-257.

Denkel, Arda. Yönletim-Dil Felsefesinde Bir Konu. Boğaziçi Üniversitesi Yayınları, No: 281, 1981.

Ekren, Uğur. "Alexius Von Meinong ve Nesneler Teorisi”. Kutadgubilig Felsefe-Bilim Araştırmalar 17 (Mart 2010): 9-26.

Fitch, Greg ve Nelson, Michael. "Singular Propositions". İçinde The Standord Encyclopedia of Philosophy, editör Edward N. Zalta, Metaphysics Research Lab Stanford University, Spring 2018. Erişim 14.12.2020, https://plato.stanford.edu/archives/spr2018/entries/propositions-singular/.

Griffin, Nicholas. "Russell's Critique of Meinong's Theory of Objects". Grazer Philosophische Studien 25 (1), (1985): 375-401.

Güven, Özgüç. "Analitik Felsefenin Tanımlayıcı Özellikleri Üstüne”. Kutadgubilig Felsefe-BilimAraştırmalar 28 (Ekim 2015): 11-24.

Koons, Robert C. ve Pickavance Timothy. H. Metaphysics: The Fundamentals. Wiley- Blackwell, 2014.

Kuşcu, Egemen S. "Analitik Felsefe: Dile Dönüşten Ontolojiye Dönüşe”. Kutadgubilig Felsefe-Bilim Arasttrmaları 31 (Eylül 2016): 117-140.

Linsky, Bernard. "Russell's Notes for Meinong's Theory of Complexes and Assumptions". Russell: the Journal of Bertrand Russell Studies 33, (2013): 143-170.

Marek, Johann. "Alexius Meinong". İçinde The Stanford Encyclopedia of Philosophy, editör Edward N. Zalta. Metaphysics Research Lab, Stanford University, Spring 2019. Erişim 14.12.2020, https://plato.stanford. edu./archives/spr2019/entries/meinong/.

Meinong, Alexius. "Theory of Objects". Realism and the Background of Phenomenology, çeviren Isaac Levi, D.B. Terrell ve Roderick M. Chisholm, editör Roderick M. Chisholm, Glencoe: Free Press, (1960): 76-117.

Perszyk, Kenneth J. Nonexistent Objects: Meinong and Contemporary Philosophy. Springer, 1993.

Pribram-Day, Ivory. "Meinong's Multifarious Being and Russell's Ontological Variable: Being in Two Object Theories across Traditions at the Turn of the 20th Century". Open Philosophy 1 (1), (2018): 310-326.

Quine, W.V.O. "On What There Is". İçinde Contemporary Readings in the Foundations of Metaphysics, editör Stephen Laurence ve Cynthia Macdonald, Blackwell, (1998): 32-45.

Russell, Bertrand. "Existential Import of Propositions". İçinde The Collected Papers of Bertrand Russell Volume 4: Foundations of Logics 1903-1905, editör Alasdair Urquhart ve Albert C. Lewis, Routledge, (1994): 486-489.

Russell, Bertrand. “Gönderim Üzerine”. Çeviren Alper Yavuz, Felsefe Tartı̧̧maları 49 (2015): 55-72.

Russell, Bertrand. "Meinong's Theory of Complexes and Assumptions (I.)". Mind 13(50), (1904): 204-219.

Russell, Bertrand. "Meinong's Theory of Complexes and Assumptions (II.)". Mind 13(51), (1904): 336-354.

Russell, Bertrand. "Meinong's Theory of Complexes and Assumptions (III.)". Mind 13(52), (1904): 509-524.

Russell, Bertrand. My Philosophical Development. Simon and Schuster, New York, 1959.

Russell, Bertrand. “On Denoting”. Mind, New Series, 14(56), (1905): 479-493.

Russell, Bertrand. Principles of Mathematics. Routledge, London and New York, 2010.

Russell, Bertrand. "Review of Meinong and Others, Untersuchungen zur Gegenstandstheorie und Psychologie". İçinde The Collected Papers of Bertrand Russell Volume 4: Foundations of Logics 1903-1905, editör Alasdair Urquhart ve Albert C. Lewis, Routledge, (1994): 596-604.

Russell, Bertrand. The Philosophy of Logical Atomism. Routledge, London and New York, Taylor \& Francis e-Library, 2009. 
Simons, Peter. Philosophy and Logic in Central Europe from Bolzano to Tarski. Springer, 1992.

Smith, Janet Farrell. The Russell-Meinong Debate". Philosophy and Phenemenological Research 45 (3), (1985): 305-350.

Swanson, Carolyn. Reburial of Nonexistents: Reconsidering the Meinong-Russell Debate. Rodopi, AmsterdamNew York, 2011.

Yavuz, Tuğba. "Varolmayan Nesneler Semantiği”. Doktora Tezi, İstanbul Üniversitesi, 2020.

Zimmerman Dean W. "Prologue: Metaphysics: After the Twentieth Century”. Oxford Studies in Metaphysics 1, (2004): 9- 22. 